\title{
Degradation of copepod faecal pellets in the upper layer: role of microbial community and Calanus finmarchicus
}

\author{
Camilla Svensen*, Christian Wexels Riser, Marit Reigstad, Lena Seuthe
}

Faculty of Biosciences, Fisheries and Economics, University of Tromsø, 9037 Tromsø, Norway

\begin{abstract}
Copepod faecal pellets (FP) are considered important contributors to vertical carbon flux, but investigations comparing FP production with FP export using sediment traps conclude that vertical export is not their only fate. FP are degraded to a large extent in the upper $60 \mathrm{~m}$, and even among large, fast-sinking FP, only a fraction reaches sediment traps deeper than $200 \mathrm{~m}$. Retention mechanisms for copepod FP are still not well understood. In order to investigate the relative importance of the small $(<180 \mu \mathrm{m})$ compartment of the plankton community versus larger filter-feeding copepods for degradation of large, fast-sinking FP, we incubated FP produced by Calanus finmarchicus (Gunnerus) in $180 \mu \mathrm{m}$-filtered water from the chlorophyll a maximum. From a series of experiments, we found that the degradation of large FP is time-dependent, as no degradation was apparent after 20 or $48 \mathrm{~h}$ of incubation, but after $72 \mathrm{~h}$ FP volume was reduced by $32 \%$. We also found that large filter-feeding copepods may facilitate the degradation process, since FP degradation increased from 0 to $75 \%$ after $48 \mathrm{~h}$ of incubation in the presence of $5 \mathrm{C}$. finmarchicus. We conclude that ciliates and dinoflagellates are able to degrade large copepod FP, but that this process is too slow to explain observed retention of large FP in the upper $200 \mathrm{~m}$ of the water column due to fast sinking of large particles. Rather than looking for single-factor explanations for flux-regulating processes, we stress the importance of investigating combined effects in relevant time frames to understand the complexity of carbon flux regulation in natural systems.
\end{abstract}

KEY WORDS: Faecal pellet - Faecal pellet retention - Microbial degradation - Faecal pellet fragmentation · Calanus finmarchicus $\cdot$ Carbon cycling

\section{INTRODUCTION}

Copepod faecal pellets (FP) are fast-sinking packages of carbon and are assumed to be a main contributor to the vertical flux of carbon in the ocean (Turner \& Ferrante 1979, and references therein). Over the last $20 \mathrm{yr}$, however, comparison of FP production and the actual downward export measured with sediment traps has revealed that highly variable, but generally strong, retention mechanisms limit FP export and facilitate recycling in the upper layers (Viitasalo et al. 1999, Wassmann et al. 1999, Wexels Riser et al. 2001, 2007, Turner 2002). The mecha- nisms and organisms involved in FP retention are still not fully understood, although some previous studies exist. For instance, as early as 1979, Paffenhöfer \& Knowles described the ingestion of FP material by copepods (Paffenhöfer \& Knowles 1979). Later, Lampitt et al. (1990) demonstrated that copepods are able to break up FP mechanically or remove the peritrophic membrane. Both mechanisms facilitate increased microbial degradation, i.e. degradation by heterotrophic bacteria as well as unicellular eucaryotes, such as heterotrophic ciliates and flagellates. Iversen \& Poulsen (2007) also suggest that FP fragmentation is caused by filter feeding and FP rejection 
by copepods. González \& Smetacek (1994) hypothesised that the abundant cyclopoid copepods Oithona spp. play a key role in the retention of copepod FP, but evidence is conflicting, indicating that Oithona spp. may be indicators for a retention community rather than the retaining organisms (Reigstad et al. 2005, Poulsen \& Kiørboe 2006). This shows that organisms other than Oithona spp. could play a major role in FP retention. In an experiment investigating the effect of various size-fractions of grazers, Poulsen \& Iversen (2008) concluded that heterotrophic ciliates and dinoflagellates are the main degraders of small FP from the calanoid copepod Acartia tonsa and that the effect of copepods on degradation rates is comparatively minor. At high latitudes, the copepod community is dominated by larger copepod species producing larger FP. It is therefore relevant to ask if the same groups of organisms and mechanisms are important for degradation of larger FP at high latitudes.

Sediment trap investigations revealed considerable attenuation of particulate organic carbon (POC) over a limited depth range $(30-60 \mathrm{~m})$ in areas where Calanus spp. dominate the larger copepod community biomass, such as the relatively productive areas on- and off-shelf along the northwest Atlantic (Andreassen et al. 1999, Olli et al. 2001), and in the Barents Sea (Reigstad et al. 2008). This depth range is often associated with a deep chlorophyll a maximum (chl $\left.a_{\max }\right)$, and/or the pycnocline. These layers have recently received increased attention as bioactive layers and sites for particle transformations (Checkley et al. 2008). Comparing vertical FP export to in situ FP production rates, there is a high but variable retention of larger and fast-sinking FP, ranging from 30 to $98 \%$ in the upper $100 \mathrm{~m}$ (Urban-Rich et al. 1999, Wexels Riser et al. 2002, 2007). High food concentrations in the chl $a_{\max }$ provide suitable conditions for high concentrations of grazers, including unicellular grazers such as heterotrophic ciliates and dinoflagellates (hereafter referred to as 'protozooplankton'). We therefore believe that this layer of high grazing activity can be important for FP degradation, and that the degradation of larger and faster-sinking FP requires efficient processes that might differ from those of smaller and slower-sinking FP.

To investigate the role of different organisms or size groups in the removal of large FP, we investigated degradation rates of Calanus finmarchicus FP (156 $\mu \mathrm{m}$ equivalent spherical diameter, ESD) by organisms $<180 \mu \mathrm{m}$ in a northern Norwegian fjord. More specifically, we performed 3 experiments to assess (1) whether FP are degraded at different rates at and below the chl $a_{\max }$ (due to the presence or absence of bioactive layers), (2) the effect of time on FP degradation, by investigating differences in degradation rate of FP after 20, 48 and $72 \mathrm{~h}$ of incubation in water from chl $a_{\max }$ and (3) the effect of C. finmarchicus on FP degradation.

\section{MATERIALS AND METHODS}

\section{Sampling and FP production}

Water was collected on 12 and 19 May 2009 at station Svartnes in Balsfjord, a $45 \mathrm{~km}$ long and 2-3 km wide fjord with SSE orientation, $\left(69^{\circ} 22^{\prime} \mathrm{N}, 19^{\circ} 07^{\prime} \mathrm{E}\right)$ (Fig. 1). Balsfjord has a maximum depth of $190 \mathrm{~m}$, and sills situated outside the mouth ( $\sim 30 \mathrm{~m}$ deep) that separate the fjord from the coastal water (Svendsen 1995, Reigstad 2000). Vertical mixing in Norwegian fjords is generally through winter convection, and fjord circulation is generated by wind forcing (Svendsen 1995). Tidal amplitudes are $2.5 \mathrm{~m}$, but the turbulence regime is not yet known. The spring bloom peaks in mid-April before any major stratification is established in the fjord (Eilertsen et al. 1981, Wexels Riser et al. 2010). The annual primary production of Balsfjord is between 105 and $130 \mathrm{~g} \mathrm{C} \mathrm{m}^{-2}$ $\mathrm{yr}^{-1}$ (Eilertsen \& Taasen 1984) and new production is approx. 30 to $40 \%$ of this (Wassmann et al. 2000). Incubation water for Expt 1 (see detailed description

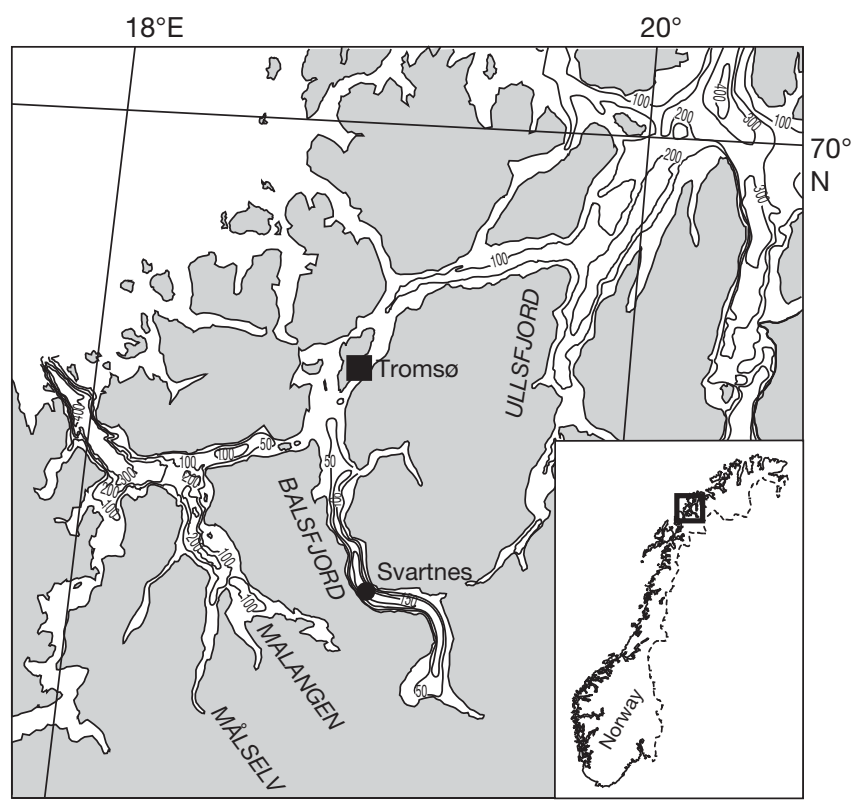

Fig. 1. Sampling station Svartnes (•), in Balsfjord, northern Norway, with bathymetry (m) 
below) was collected at depths of 60 and $90 \mathrm{~m}$ on 12 May, in order to sample both the chl $a_{\max }$ and below the pycnocline, respectively. For Expts 2 and 3 , water was only collected at the depth of the chl $a_{\max }(20 \mathrm{~m})$ on $19 \mathrm{May}$, in order to investigate time-dependent FP degradation.

At the time of sampling, a CTD profile was taken and samples for suspended chl $a$, POC and particulate organic nitrogen (PON) were collected with Niskin water bottles at 10,20,30,40,50, 90, 120 and $200 \mathrm{~m}$. Depth of chl $a_{\max }$, and hence sampling depth of incubation water for the experiments, was determined from the fluorescence profile obtained with the CTD. Samples for enumeration and identification of protozooplankton were collected from the incubation water depths and preserved in $2 \%$ acid Lugol's solution.

Copepods for the experiments were collected near the station at least $1 \mathrm{~d}$ prior to the start of the experiments to allow production of FP. Large individuals (Stage CV and females between 2.2 and $2.7 \mathrm{~mm}$ prosome length) of Calanus finmarchicus were sorted under a dissecting microscope equipped with a cold light in a temperature controlled room at $6^{\circ} \mathrm{C}$. FP were produced in two $10 \mathrm{l}$ beakers by allowing approx. 65 C. finmarchicus to graze on a culture of

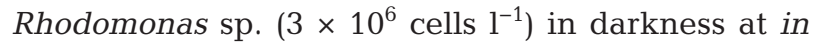
situ temperature $\left(6^{\circ} \mathrm{C}\right)$. After approx. $10 \mathrm{~h}$, the bottom content of the beakers was siphoned off into smaller beakers and the FP were sorted under a dissecting microscope. FP were always kept on ice during the sorting process and were rinsed 3 times in filtered seawater before being added to the experimental bottles. Only intact FP were selected for the experiments, and total handling time for the FP was a maximum of $6 \mathrm{~h}$. The mean \pm SD size of individual FP was $590 \pm 97 \mu \mathrm{m}$ length and $66 \pm 10 \mu \mathrm{m}$ width $(\mathrm{n}=$ 100) (Table 1), corresponding to an average ESD of $156 \mu \mathrm{m}$. The approximate sinking rate for similarsized FP was estimated in settling experiments to be

Table 1. Properties of faecal pellets (FP) used in the degradation experiments. Length, width, volume, carbon content, nitrogen content and carbon:volume $(\mathrm{C}: \mathrm{V})$ ratio of pellets produced by Calanus finmarchicus feeding on Rhodomonas sp. (mean $\pm \mathrm{SD}, \mathrm{n}=100)$

$$
\begin{aligned}
& \text { Length }(\mu \mathrm{m}) \\
& \text { Width }(\mu \mathrm{m}) \\
& \text { Volume }\left(\mu \mathrm{m}^{3}\right) \\
& \text { Carbon }\left(\mu \mathrm{g} \mathrm{C} \mathrm{FP}{ }^{-1}\right) \\
& \text { Nitrogen }\left(\mu \mathrm{g} \mathrm{N} \mathrm{FP}{ }^{-1}\right) \\
& \mathrm{C}: \mathrm{V}\left(\mu \mathrm{g} \mathrm{C} \mathrm{m^{-3 } )}\right.
\end{aligned}
$$

between 100 and $200 \mathrm{~m} \mathrm{~d}^{-1}$ (E. Arashkevich and C. Wexels Riser, unpubl. data). The Rhodomonas sp. culture originated from the Canadian Arctic and was grown at $6^{\circ} \mathrm{C}$ in $\mathrm{f} / 2$ medium.

\section{Experiments}

Three experiments were performed to investigate FP degradation caused by the microbial community (Expts 1 and 2) and FP removal caused by Calanus finmarchicus (Expt 3) (Table 2). All experiments were run in a temperature-controlled room $\left(6^{\circ} \mathrm{C}\right)$ in the dark. Freshly produced FP were incubated in $600 \mathrm{ml}$ bottles on a slowly rotating (1 rpm) plankton wheel to keep FP in suspension during the experiments. All incubation water was screened through $180 \mu \mathrm{m}$ Nitex mesh to exclude patchy occurrence of large organisms, but keep the protozooplankton community at natural concentrations.

\section{Expt 1}

To investigate the differences in microbial degradation of FP at 2 depths, we incubated 80 freshly produced FP for $20 \mathrm{~h}$ in (1) water from below the pycnocline (90 m depth), (2) water from the chl $a_{\max }(60 \mathrm{~m}$ depth) and (3) $0.22 \mu \mathrm{m}$-filtered seawater (FSW) as a control. All treatments had 4 replicates. At the end of the experiment, before collecting the remaining $\mathrm{FP}$, bottles were left for $30 \mathrm{~min}$ on the bench to allow the FP to sink. Thereafter, incubation water was gently reduced to $200 \mathrm{ml}$ using a silicon tube covered with a $10 \mu \mathrm{m}$ filter to prevent accidental removal of FP. The remaining water was fixed with formalin $(2 \%$ final concentration). FP were counted and their length and width measured after $24 \mathrm{~h}$ sedimentation in Utermöhl chambers using an inverted microscope (Leica DM IL) at $100 \times$ magnification. Note that counting and measuring all FP fragments at $100 \times$ magnification is necessary for obtaining the high precision biovolume measurements needed for investigating FP degradation, as counting but not measuring FP at lower magnification would result in higher and erroneous degradation rates.

\section{Expt 2}

The design of Expt 2 was similar to Expt 1, but the incubation water was only collected at the chl $a_{\max }$ (20 $\mathrm{m}$ depth). To investigate the effect of time on FP 
Table 2. Experimental set-up, incubation time (inc. time) and properties of incubation water (Inc. water) for Expts 1-3. FP: faecal pellets; chl $a_{\text {max }}$ : depth of chlorophyll a maximum; FSW: filtered seawater

\begin{tabular}{|c|c|c|c|c|}
\hline Expt & $\begin{array}{l}\text { Date } \\
\text { (d.mo.yr) }\end{array}$ & $\begin{array}{l}\text { Inc. time } \\
\text { (h) }\end{array}$ & $\begin{array}{l}\text { Inc. water } \\
\text { (replicates) }\end{array}$ & Purpose \\
\hline 1 & 12.05 .09 & 20 & $\begin{array}{l}\text { Chl } a_{\max }: 60 \mathrm{~m}(4) \\
\text { In situ } 90 \mathrm{~m}(4) \\
\text { Control: FSW (4) }\end{array}$ & $\begin{array}{l}\text { FP degradation from } \\
\text { microbial community } \\
<180 \mu \mathrm{m} \text { after } 20 \mathrm{~h}\end{array}$ \\
\hline 2 & 19.05 .09 & $\begin{array}{l}48 \\
72\end{array}$ & $\begin{array}{l}\text { Chl } a_{\max }: 20 \text { m (4) } \\
\text { Control: FSW (4) } \\
\text { Chl } a_{\max }: 20 \text { m (4) } \\
\text { Control: FSW (4) }\end{array}$ & $\begin{array}{l}\text { FP degradation } \\
\text { from microbial } \\
\text { community }<180 \mu \mathrm{m} \\
\text { after } 48 \text { and } 72 \mathrm{~h}\end{array}$ \\
\hline 3 & 20.05 .09 & 48 & $\begin{array}{l}\text { Chl } a_{\max }: 20 \mathrm{~m}(4) \\
\text { Control: } c h l a_{\max } \\
20 \mathrm{~m}(4)\end{array}$ & $\begin{array}{l}\text { Mechanical frag- } \\
\text { mentation of FP by } \\
\text { Calanus finmarchicus }\end{array}$ \\
\hline
\end{tabular}

degradation by the $<180 \mu \mathrm{m}$ community, the incubation time was prolonged to 48 and $72 \mathrm{~h}$. In total, 16 bottles containing 80 FP each were incubated. Eight bottles were incubated for $48 \mathrm{~h}$ (4 replicates, 4 controls), and 8 bottles were incubated for $72 \mathrm{~h}$ (4 replicates, 4 controls). Treatment bottles contained FP and $180 \mu \mathrm{m}$-screened water from $20 \mathrm{~m}$ depth, and the control bottles contained FP and FSW. The procedure for ending the experiment was the same as for Expt 1.

\section{Expt 3}

The last experiment investigated FP degradation in the presence of both Calanus finmarchicus and the microbial community $<180 \mu \mathrm{m}$. We used incubation water from the chl $a_{\max }(20 \mathrm{~m})$, as for Expt 2 . Four bottles, each containing $80 \mathrm{FP}$, were incubated with filtered $(180 \mu \mathrm{m})$ water from the $\mathrm{chl} a_{\max }$ while $5 \mathrm{C}$. finmarchicus were added to another 4 incubation bottles containing filtered water from the chl $a_{\max }$ and $80 \mathrm{FP}$. An additional 4 bottles filled with FSW and 80 FP served as a control. Prior to the experiment, the copepods were left overnight in FSW to empty their guts. The experiment was terminated after $48 \mathrm{~h}$ as described for Expt 1 and 2.

\section{Chl a, POC, and FP analyses}

Chl a concentrations in the incubation water and in situ profiles were measured on a Turner Designs model 10-AU fluorometer calibrated using pure chl a (Sigma C6144). Samples were filtered onto GF/F (total chl a) and membrane filters (chl $a>10 \mu \mathrm{m}$ ) and extracted in $100 \%$ methanol overnight (Holm-
Hansen et al. 1965). Samples for POC and PON were filtered in triplicate onto pre-combusted GF/F filters, frozen $\left(-20^{\circ} \mathrm{C}\right)$ and analysed on a Leeman Lab 440 elemental analyser. Prior to analyses, inorganic carbon was removed by fuming filters with concentrated $\mathrm{HCl}$. We also determined carbon content of the FP used in the degradation experiments (3 replicates containing $100 \mathrm{FP}$ each). The average volume of 100 measured FP was used to estimate a carbon:volume conversion for Calanus finmarchicus FP. The carbon content of the FP used in the experiments was $123.2 \mu \mathrm{g} \mathrm{C} \mathrm{mm}^{-3}$, equivalent to $0.26 \mu \mathrm{g} \mathrm{C} \mathrm{FP}{ }^{-1}$. This implies that $20.5 \mu \mathrm{g}$ of faecal pellet carbon (FPC) was added to each experimental bottle. Incubation water was checked for 'background' FP.

\section{In situ plankton community determinations}

Ciliates and heterotrophic dinoflagellates were enumerated under an inverted microscope (Leica DM IL) at 200× magnification in accordance with Utermöhl (1958). Cell sizes were measured and geometric proxies were used to calculate biovolume of the cells. The biovolume was converted to carbon using a volume to carbon conversion factor of $0.19 \mathrm{pg}$ C $\mu \mathrm{m}^{-3}$ (Putt \& Stoecker 1989) for aloricate ciliates. The carbon content of dinoflagellates was calculated in accordance with Menden-Deuer \& Lessard (2000) as pg $\mathrm{C} \mathrm{cell}^{-1}=0.76 \times \mathrm{Vol}^{0.819}$, where $\mathrm{Vol}=$ cell volume $\left(\mu \mathrm{m}^{3}\right)$. The samples were screened for small metazoan zooplankton (i.e. copepod nauplii and meroplankton), which could have passed through the $180 \mu \mathrm{m}$ screen. No such grazers were found; therefore, the grazer community $<180 \mu \mathrm{m}$ used in the experiments consisted entirely of protozooplankton.

\section{Statistical analyses}

Data were checked for normality, and differences in FPC in control (FSW) and treatment (chl $a_{\max }$ ) bottles were tested for statistical significance using a 2-way ANOVA with time and treatment as factors. Differences between the treatments in the $48 \mathrm{~h}$ incubations (chl $a_{\max }$, Calanus) and the control (FSW) were tested for statistical differences using paired Student's $t$-tests (SPSS16.0). 
Table 3. Depth of chlorophyll a maximum $\left(\mathrm{chl} a_{\max }\right)$, temperature and salinity at the sampling station Svartnes on the 2 dates sampled. Water for Expt 1 was sampled 12.05.09, and water for Expts 2 and 3 was sampled 19.05.09

\begin{tabular}{|lccccccc|}
\hline $\begin{array}{l}\text { Date } \\
(\text { d.mo.yr })\end{array}$ & $\begin{array}{c}\text { Depth of } \\
\mathrm{chl} a_{\max } \\
(\mathrm{m})\end{array}$ & $\begin{array}{c}\text { Temperature } \\
\text { at chl } a_{\max } \\
\left({ }^{\circ} \mathrm{C}\right)\end{array}$ & $\begin{array}{c}\text { Salinity at } \\
\text { chl } a_{\text {max }}\end{array}$ & $\begin{array}{c}\text { Temperature } \\
\text { range, } \\
0-60 \mathrm{~m}\left({ }^{\circ} \mathrm{C}\right)\end{array}$ & $\begin{array}{c}\text { Salinity } \\
\text { range, } \\
0-60 \mathrm{~m}\end{array}$ & $\begin{array}{c}\text { Average } \\
\text { temperature, } \\
60-100 \mathrm{~m}\left({ }^{\circ} \mathrm{C}\right)\end{array}$ & $\begin{array}{c}\text { Average } \\
\text { salinity, } \\
60-100 \mathrm{~m}\end{array}$ \\
\hline 12.05 .09 & 60 & 2.7 & 33.56 & $2.7-5.5$ & $32.0-33.6$ & 2.76 & 33.6 \\
19.05 .09 & 20 & 4.5 & 33.28 & $2.8-7.5$ & $31.1-33.6$ & 2.81 \\
\hline
\end{tabular}

\section{RESULTS}

\section{Physical and biological background for experiments}

Physical and biological parameters were measured at the sampling station Svartnes in Balsfjord on 2 occasions in order to obtain information about the incubation water for the experiments (Table 3). The main difference between the 2 sampling occasions was the depth of chl $a_{\text {max }}$, which was $60 \mathrm{~m}$ on May 12 due to a wind event prior to sampling, and $30 \mathrm{~m}$ on May 19, when the wind had eased (Fig. 2). The deep chl $a_{\max }$ at $60 \mathrm{~m}$ on May 12 had concentrations of chl $a$ and $P O C$ of 3 and $250 \mathrm{mg} \mathrm{m}^{-3}$, respectively. On May 19, the concentrations were within the same range as the first sampling date (Fig. 2). The chl a concentrations were dominated by phytoplankton cells $<10 \mu \mathrm{m}$ (91 and $84 \%$ on May 12 and May 19, respectively) (data not shown). The deep mixing also influenced water-column properties such as average temperature and salinity in the upper $60 \mathrm{~m}$ (Table 3). than the assemblage at $90 \mathrm{~m}$ in terms of ESD. The same trend was observed for the ciliate assemblage from these 2 depths, with ciliates being on average 12 $\mu \mathrm{m}$ larger at $60 \mathrm{~m}$. At $60 \mathrm{~m}$, oligotrich ciliates of the

Table 4. Concentrations of chlorophyll a $(\mathrm{chl} a)$, particulate organic carbon (POC) and protozooplankton in the incubation water collected at 60,90 and $20 \mathrm{~m}$ depth at the start $\left(t_{0}\right)$ of Expts 1-3. ESD: equivalent sperical diameter

\begin{tabular}{|c|c|c|c|}
\hline 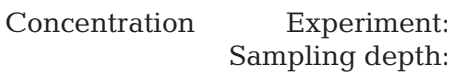 & $\begin{array}{c}1 \\
60 \mathrm{~m}\end{array}$ & $\begin{array}{c}1 \\
90 \mathrm{~m}\end{array}$ & $\begin{array}{l}2+3 \\
20 \mathrm{~m}\end{array}$ \\
\hline Chl a $\left(\mu g \mathrm{l}^{-1}\right)$ & 3 & 0.3 & 2 \\
\hline POC $\left(\mu g l^{-1}\right)$ & 254 & 98 & 209 \\
\hline Total ciliates $\left(\mu \mathrm{g} \mathrm{C}^{-1}\right)$ & 3 & 0 & 50 \\
\hline Strombidium spp. & 3 & 0 & 22 \\
\hline Laboea strobila & 0 & 0 & 18 \\
\hline Other ciliates & 1 & 0 & 10 \\
\hline Total dinoflagellates $\left(\mu \mathrm{g} \mathrm{C} \mathrm{l}^{-1}\right)$ & 9 & 2 & 26 \\
\hline Athecate ESD 10-30 $\mu \mathrm{m}$ & 1 & 2 & 16 \\
\hline Athecate ESD 30-50 $\mu \mathrm{m}$ & 5 & 0 & 4 \\
\hline Other dinoflagellates & 3 & 0 & 7 \\
\hline Total protozooplankton $\left(\mu \mathrm{gC} \mathrm{l}^{-1}\right)$ & 12 & 2 & 76 \\
\hline
\end{tabular}

\section{Protozooplankton in the incubation water}

Water for Expt 1, sampled at the chl $a_{\max }$ at $60 \mathrm{~m}$ depth on May 12, had a protozoan biomass of $12 \mu \mathrm{g} \mathrm{C} \mathrm{l^{-1 }}$ (Table 4). Athecate dinoflagellates dominated in both numbers and biomass. Small athecate dinoflagellates $(\mathrm{ESD}<30 \mu \mathrm{m})$ were numerically most abundant, but dominated in terms of biomass only in the water from $90 \mathrm{~m}$ (Table 4). At $60 \mathrm{~m}$, larger athecates (ESD >30 $\mu \mathrm{m})$ constituted the largest fraction of dinoflagellate biomass, dominated by dinoflagellates of the genus Gyrodinium (average ESD $41 \mu \mathrm{m})$. The dinoflagellate assemblage at $60 \mathrm{~m}$ was on average $20 \mu \mathrm{m}$ larger

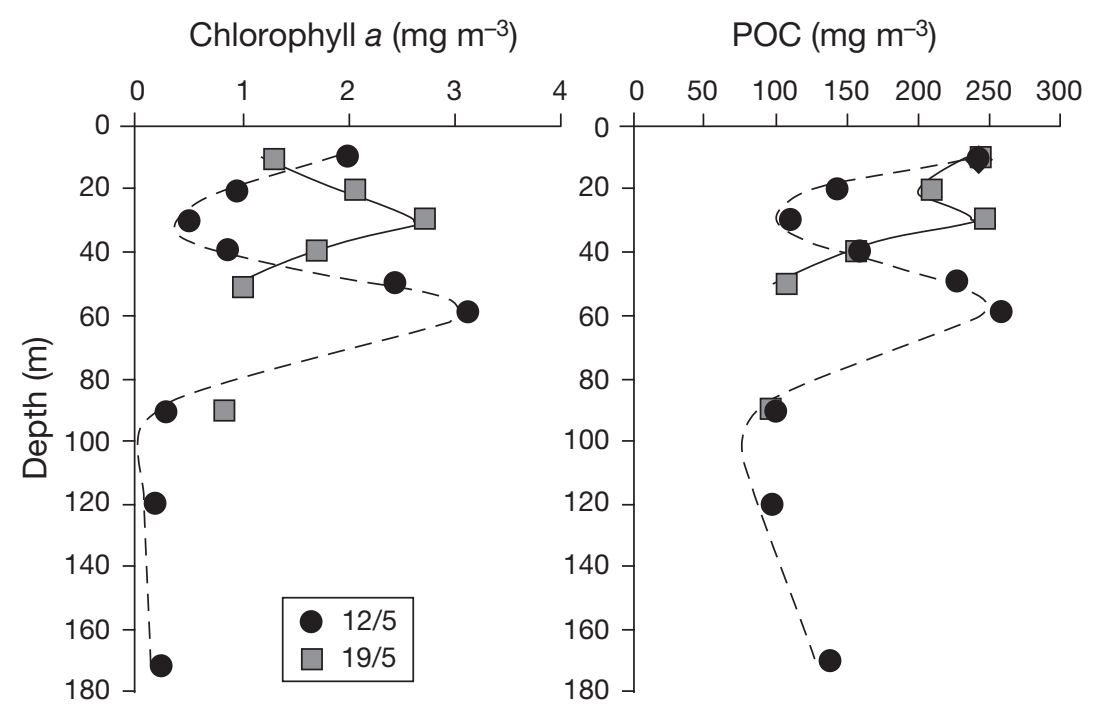

Fig. 2. Vertical profiles of chlorophyll a $(\mathrm{chl} a)$ and particulate organic carbon (POC) on 12 and 19 May 2009 
genus Strombidium dominated the ciliate assemblage, constituting $\geq 60 \%$ of the numbers and biomass. At 90 m, small (average ESD $15 \mu \mathrm{m}$ ) aloricate choreotrichs (genera Lohmanniella and Leegaardiella) were numerically most abundant, but strombidiids (average ESD $20 \mu \mathrm{m}$ ) dominated the biomass.

The incubation water for Expts 2 and 3 was collected on May 19 from $20 \mathrm{~m}$ depth, at the chl $a_{\max }$ (according to the CTD profile). Total biomass of protozoans was $76 \mu \mathrm{g} \mathrm{C}^{-1}$ (Table 4). Numerically, small (ESD $<30 \mu \mathrm{m})$ heterotrophic dinoflagellates dominated the protozoan assemblage. In terms of biomass, however, ciliates were more important due to the occurrence of the large oligotrichs, Strombidium cf. constrictum and Laboea strobila, with average ESDs of 63 and $103 \mu \mathrm{m}$, respectively. Large strobilidiids (ESD $\geq 70 \mu \mathrm{m})$ were also present. The larger dinoflagellates were dominated by Gyrodinium spp., which ranged in ESD from 49 to $97 \mu \mathrm{m}$.

\section{Degradation of faecal pellets}

Copepod FP were incubated in FSW and water from the chl $a_{\max }$ for 20,48 and $72 \mathrm{~h}$. In addition, FP were incubated for $20 \mathrm{~h}$ in water collected from below the pycnocline at $90 \mathrm{~m}$ depth, as part of Expt 1. No statistically significant difference in FP recovery was found after 20,48 and $72 \mathrm{~h}$ in FSW ( $p>0.05$ ) (Fig. 3A). This was confirmed by microscopic observations of FP after incubation (Fig. 4).

FP incubated with water containing the microbial community $<180 \mu \mathrm{m}$, i.e. containing protozooplankton, were not significantly degraded after 20 or $48 \mathrm{~h}$ incubation, and FPC was not statistically significantly different from the control bottles containing FP in FSW (Fig. 3A,B). FP incubations $(20 \mathrm{~h})$ in water from $90 \mathrm{~m}$ depth were not included in Fig. 3, since there was no significant difference between incubations from 60 and $90 \mathrm{~m} \mathrm{(p} \mathrm{>0.05).} \mathrm{The} \mathrm{only}$ significant effect of the microbial community on FP degradation occurred after $72 \mathrm{~h}$ incubation time $(\mathrm{p}<0.05)$, where $32 \%$ of the initial FPC was removed compared to the control bottles containing FP in FSW. The extent of FP fragmentation also increased from $\sim 0 \%$ after $48 \mathrm{~h}$ to $\sim 40 \%$ after $72 \mathrm{~h}$ (data not shown). Compared to the shorter incubations, the FP appeared more fragmented after $72 \mathrm{~h}$ (Fig. 4).

In the bottles where Calanus finmarchicus were added to the incubation water containing the microbial community (Expt 3), FPC was significantly reduced compared to FPC in the FSW and chl $a_{\max }$ treatments after $48 \mathrm{~h}(\mathrm{p}<0.01)$ (Fig. 3C). Visual inspection demonstrated that the FP from the $C$. finmarchicus treatment were broken into many pieces, in a different way than the FP incubated for $72 \mathrm{~h}$ in water from the chl $a_{\max }$ (Fig. 4). The total FPC removal was $75 \%$, corresponding to a daily removal rate of $37 \%$. However, as we must assume that the degradation took place between 48 and $72 \mathrm{~h}$, it is misleading to operate with a daily removal rate calculated as the average over $72 \mathrm{~h}$.

\section{DISCUSSION}

We investigated the degradation of large Calanus finmarchicus FP after different time intervals by exposure to FSW and the microbial community, with or without the presence of $C$. finmarchicus. Incubations in FSW did not demonstrate a time-dependent

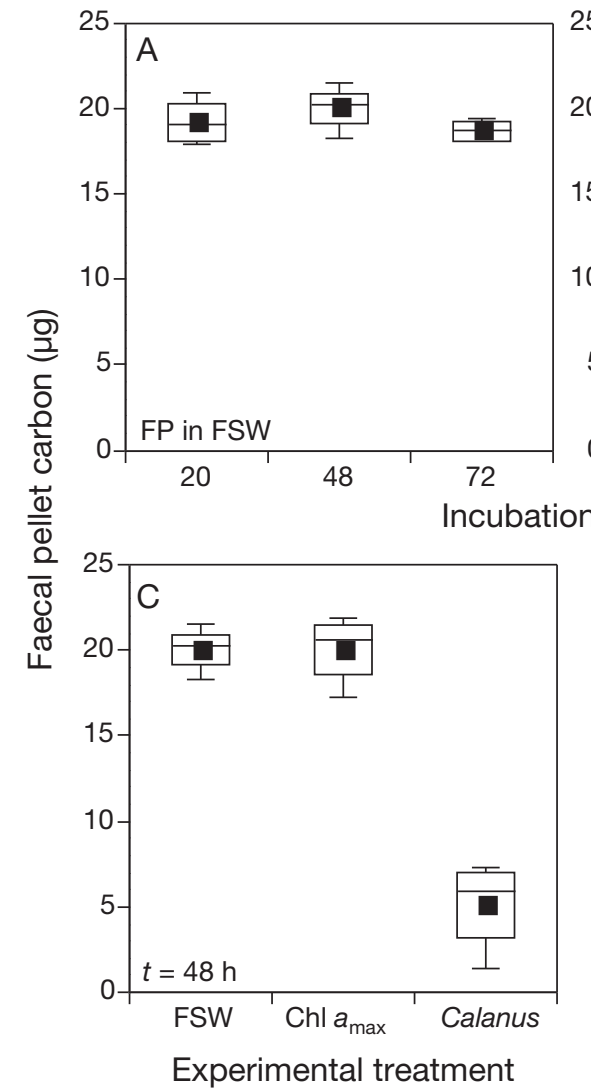

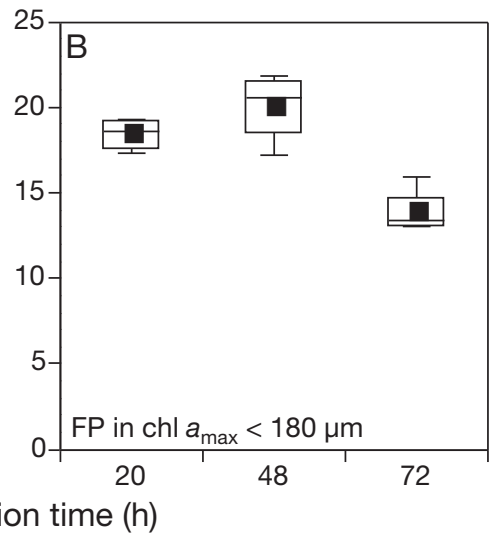

Fig. 3. Faecal pellet carbon (FPC) in the experiments after 20, 48 and $72 \mathrm{~h}$ in (A) filtered seawater (FSW), (B) water collected at the chlorophyll a maximum (chl $a_{\max }$ ) containing the microbial community $<180 \mu \mathrm{m}$ and (C) comparison of FPC after $48 \mathrm{~h}$ incubation with FSW, water from the chl $a_{\max }$ and 5 Calanus finmarchicus females 


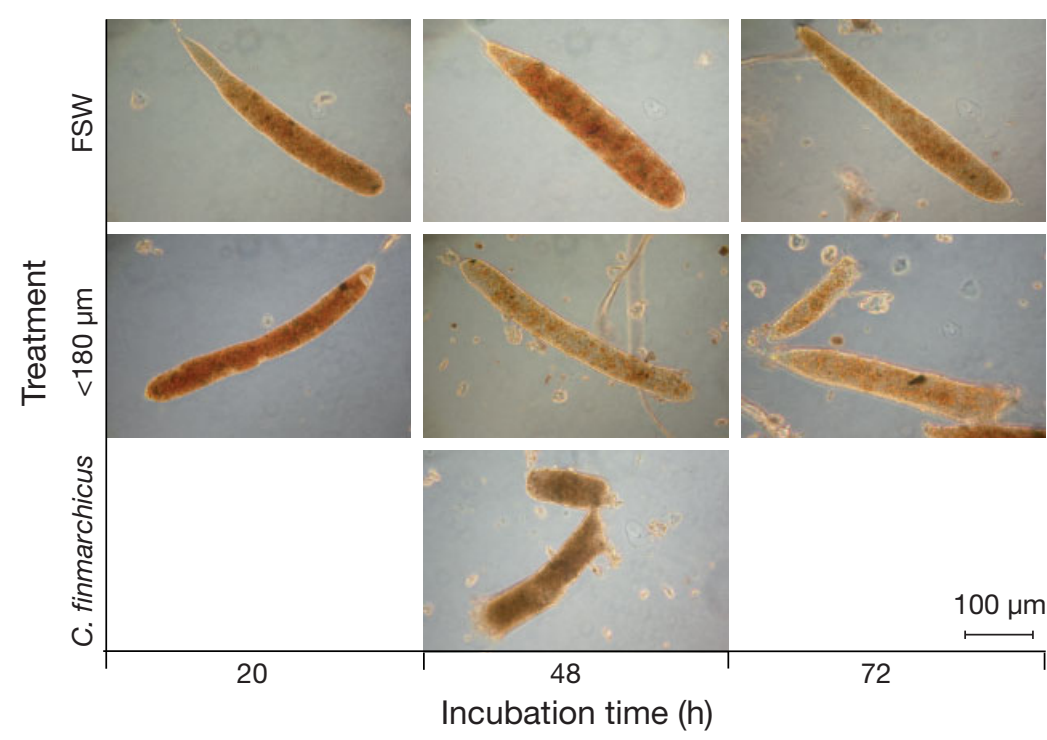

Fig. 4. Faecal pellets incubated with filtered seawater (FSW), the microbial community $<180 \mu \mathrm{m}$ and Calanus finmarchicus, with time

function of pellet concentration, due to increased encounter rates between the pellets and the degrader organisms. The pellet concentration in the experiments conducted by Poulsen \& Iversen (2008) was $0.5 \mathrm{FP} \mathrm{ml} \mathrm{m}^{-1}$; about 10 -fold greater than our experiments $\left(0.08 \mathrm{FP} \mathrm{ml}^{-1}\right)$. A FP volume equal to $0.26 \mathrm{~mm}^{3} \mathrm{l}^{-1}$ was added in the present experiments. This is within the natural range of suspended FP concentrations previously observed in Balsfjord (up to $0.11 \mathrm{~mm}^{3} \mathrm{l}^{-1}$, Wexels Riser et al. 2010) and on the northern Norwegian shelf (up to $0.36 \mathrm{~mm}^{3} \mathrm{l}^{-1}$, Wassmann et al. 1999). (3) Differences in degradation rates may be explained by differences in the abundance and composition of the degrader organisms. In Expt 2, where the highest microbial degradation rates were found, the protozooplankton community was dominated by ciliates $\left(50 \mu \mathrm{g} \mathrm{C}^{-1}\right)$, although hetero-

difference in FP degradation and fragmentation within $72 \mathrm{~h}$, and we therefore conclude that FP degradation due to ageing, or fragmentation due to handling and incubation on the plankton wheel, were not of importance in our experiments.

\section{Time-dependent FP degradation by the microbial community}

Our results indicated that (1) the $<180 \mu \mathrm{m}$ microbial community was capable of significantly degrading the large FP produced by Calanus finmarchicus, and (2) this was a relatively slow process, as loss of faecal material was only detected after $72 \mathrm{~h}$ of incubation, in contrast to previous investigations (Poulsen \& Iversen 2008).

Degradation rates of small FP produced by Acartia tonsa range from 22 to $87 \% \mathrm{~d}^{-1}$, and biota measuring $<200 \mu \mathrm{m}$, particularly dinoflagellates, are reported to be the main degraders (Poulsen \& Iversen 2008). The daily pellet degradation rates found by Poulsen \& Iversen (2008) after 24 and $48 \mathrm{~h}$ of incubation are much higher than in our study, raising some important points. (1) Faecal pellet degradation rates are likely size-dependent. Pellets produced by A. tonsa are considerably smaller (volume 3-12 × 104 $\mathrm{\mu m}^{3}$, ESD $\sim 50 \mu \mathrm{m})$ than those produced by Calanus finmarchicus (volume $2 \times 10^{6}{\mu \mathrm{m}^{3}}^{3}$, Table $1, \mathrm{ESD}=$ $156 \mu \mathrm{m})$ and thus closer to the preferred prey size of protozooplankton. (2) Degradation rates may be a trophic dinoflagellates were also abundant $(26 \mu \mathrm{g} \mathrm{C}$ $\mathrm{l}^{-1}$ ). However, most dinoflagellates were $<30 \mu \mathrm{m}$ ESD, and dinoflagellates $>30 \mu \mathrm{m}$ only contributed $4 \mu \mathrm{g} \mathrm{C} \mathrm{l}^{-1}$. In comparison, large dinoflagellates $(>20 \mu \mathrm{m})$ contributed a maximum of $15 \mu \mathrm{g} \mathrm{Cl}^{-1}$ in the study by Poulsen \& Iversen (2008).

While ciliates have a prey preference of $1 / 10$ of their own body size and select prey $<20 \mu \mathrm{m}$, dinoflagellates may feed on particles several times larger than themselves, with an optimal prey size of 1/1 (Hansen 1992, Jakobsen \& Hansen 1997). Although the FP in our experiments were large $(590 \times 97 \mu \mathrm{m}$ on average, average ESD $156 \mu \mathrm{m})$, they could potentially, but not optimally, have been fed upon by Gyrodinium spp. (average ESD $41 \mu \mathrm{m}$ ), which dominated the large dinoflagellate assemblage. Poulsen et al. (2011) suggested that FP > $400 \mu \mathrm{m}$ might be too large for most phagotrophic dinoflagellates to graze upon. Difficulties with handling large FP might explain why degradation of Calanus finmarchicus FP was only apparent after $72 \mathrm{~h}$ in our study. However, the FP were certainly too large for ciliates to feed upon, though they may have caused physical damage to the periotrophic membrane, as reported by Lampitt et al. (1990). Total protozooplankton biomass was low in the water collected at 60 ( $\mathrm{chl} a_{\max }$ ) and $90 \mathrm{~m}$ depths, and this, in addition to the short incubation time, may explain why $C$. finmarchicus FP were not degraded in Expt 1. We thus conclude that both incubation time and FP size are important variables for FP degradation rates. 


\section{FP degradation by copepods}

The role of copepods and large zooplankton in FP degradation is still under debate. Copepods may impact FP through ingestion (coprophagy), mechanical break-up (coprorhexy) or by destroying the membrane (coprochaly) (Lampitt et al. 1990, Noji 1991). Paffenhöfer \& Van Sant (1985) showed that the copepod Eucalanus pileatus feeds on, but does not positively select for, FP from Paracalanus spp. Harpacticoid copepods such as Oncea spp. feed on the surfaces of FP, and have the potential to retain the FP material in the upper layers of the southern Indian Ocean (Møller et al. 2011). The benthic harpacticoid copepod Paramphiascella fulvofasciata also ingests FP (De Troch et al. 2009). Iversen \& Poulsen (2007) showed that Calanus helgolandicus actively reject FP from Acartia tonsa during filter feeding, resulting in FP fragmentation. Recent studies on the relative impact of smaller versus larger zooplankton on FP degradation concluded that copepods and zooplankton $>200 \mu \mathrm{m}$ do not play an important role in the degradation of pellets from the natural zooplankton community in the Baltic Sea, where Oithona spp. and smaller calanoid copepods, such as $A$. tonsa, are most abundant (Poulsen \& Kiørboe 2006, Poulsen \& Iversen 2008, respectively). In these studies, heterotrophic dinoflagellates and late stage nauplii were the most important degraders.

Most of the aforementioned experiments are concerned with the degradation of FP of smaller copepods, with an ESD in the feeding size range of protozooplankton. From field studies, we know that the retention of small FP is high, as their contribution to vertical export at depth is minor despite high abundance of small zooplankton (Wexels Riser et al. 2008, 2010). However, the retention mechanism of larger FP, which contribute to vertical export, but are also partly retained (Wexels Riser et al. 2002) is still uncertain.

Our experiments showed that Calanus finmarchicus had a significant effect on removal rates of larger C. finmarchicus FP. The average FP removal from bottles containing both microbes $<180 \mu \mathrm{m}$ and C. finmarchicus was $37 \% \mathrm{~d}^{-1}$ (Expt 3 ). This corresponds to a pellet clearance rate, calculated in accordance with Frost (1972), of $83 \pm 14 \mathrm{ml}$ copepod ${ }^{-1} \mathrm{~d}^{-1}$ (mean $\pm \mathrm{SD}$ at $6^{\circ} \mathrm{C}$ ). In comparison, $C$. helgolandicus has a clear-

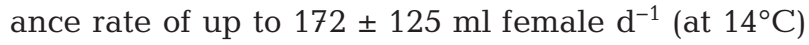
when feeding on pellets from Acartia tonsa (Iversen \& Poulsen 2007). Correcting for the difference in temperature using a $Q_{10}$ of 2.8 (Hansen et al. 1997), our rates for $C$. finmarchicus feeding on FP are higher (234 ml female $\left.\mathrm{e}^{-1} \mathrm{~d}^{-1}\right)$, but in the same order of magnitude, as clearance rates reported by Iversen \& Poulsen (2007). Our results therefore support the conclusions of Iversen \& Poulsen (2007) that when a filter-feeding copepod encounters a FP, the pellet is often rejected, and ingestion occurs only when fragments are so small that they are ingested unintentionally with other food particles. Based on the photos of FP incubated with $C$. finmarchicus (Expt 3), it seems that FP were cut open, and when counting the FP material we noted many small FP fragments (Fig. 4). We suggest that the missing FP material in Expt 3 was ingested by $C$. finmarchicus, although FP were perhaps not the target food. The need to look at additive effects also gives rise to the hypothesis that larger copepods facilitate the degradation of FP material by making it more available for complex microbial processes (Ploug et al. 2008). In our case, it is probable that successive processes are present, where the 'FP breakers' are the first step in the degradation of larger FP.

\section{In situ downward flux and degradation of copepod FP}

The size and sinking speed of FP determines its residence time in the upper layer of the ocean, as increased residence time implies greater exposure to degrader organisms in the 'retention filter' (sensu Wexels Riser et al. 2001). Several functional or compositional models defining such retention filters have been suggested, such as the coprophagous filter (Gonzales \& Smetacek 1994) and the protozooplankton filter (Poulsen \& Iversen 2008). We suggest that the retention filter that most adequately describes the observed retention processes is the layer of increased grazing activity observed at the base of the surface mixed layer, related to the chl $a_{\max }$ as described by Checkley et al. (2008). The high concentration of grazers attracted to this area by increased food availability increases the retention of FP through fragmentation as well as feeding on FP or FP fragments.

The sinking rate of FP varies greatly and is a function of size, shape and density. Also, measured sinking velocities on ellipsoid pellets can be higher than those calculated from Stoke's law, which assumes a spherical shape (Ploug et al. 2008). For ellipsoid FP produced by Eucalanus pileatus (volume $2.5 \pm 0.2 \times$ $10^{6} \mathrm{\mu m}^{3}$, mean $\pm \mathrm{SD}$ ) fed with Thalassiosira weissflogii, the sinking velocity is $36.4 \pm 3.8 \mathrm{~m} \mathrm{~d}^{-1}$ (Patonai et al. 2011). Small et al. (1979) reported sinking 
velocities for similar-sized FP ranging from 30 to $100 \mathrm{~m} \mathrm{~d}^{-1}$, and attributed the variability to different diets of the FP producers. A clear effect of copepod diet on FP sinking velocities was also found for Temora longicornis; FP produced on a Rhodomonas sp. diet sink more slowly $\left(35 \pm 29 \mathrm{~m} \mathrm{~d}^{-1}\right)$ than those produced on a Emiliania huxleyi $\left(200 \pm 93 \mathrm{~m} \mathrm{~d}^{-1}\right)$ and T. weissflogii diet $\left(322 \pm 169 \mathrm{~m} \mathrm{~d}^{-1}\right.$ ) (Ploug et al. 2008). In a seasonal study in Balsfjord, the mean sinking rate of copepod FP was100 to $200 \mathrm{~m} \mathrm{~d}^{-1}$ (A. Arashkevich \& C. Wexels Riser unpubl. data). As pellets produced on a diatom diet have lower carbon content and higher sinking rates than pellets produced on a flagellate diet, FP produced on a flagellate diet are more likely to be recycled within the euphotic zone than those produced on a diatom diet (Urban-Rich 2001). This implies that the content of the FP also affects degradation and hence contribution to the vertical flux of organic carbon from the euphotic zone.

Consequently, the efficiency of the retention filter is not only dependent on the composition of the filter, but also on the properties of the particles that pass through it. We must therefore distinguish between retention mechanisms relevant for small and large FP. In our experiments, the microbial degradation of the large FP produced by Calanus finmarchicus was only detectable after $72 \mathrm{~h}$, and given the residence time of natural FP in the upper $100 \mathrm{~m}$ in Balsfjord, the FP would have reached the seafloor within that time frame. Hence, large FP sink quickly through the euphotic zone where the most efficient degradation takes place. The low sinking rate of small FP is one likely explanation why few FP produced by small copepods, such as Acartia spp. and similar, are found at depth and why the size of FP increases with depth of capture (Hofmann et al. 1981, Ayukai \& Hattori 1992, Cadée et al. 1992, Wexels Riser et al. 2008).

For plankton communities, export of organic material (including copepod FP) represents a loss of nutrients that could potentially fuel continued production. Regenerated production, which is typical in most systems after the spring bloom, is dependent on recycling of the nutrient pool. Recycling of nutrients in the euphotic zone is linked to processes within the retention filter. To fully comprehend export and retention processes, we must address the relevant time scales. Not only must processes and key players be investigated experimentally, but results must be interpreted in light of field data and existing knowledge. Vertical export of biogenic particles and retention processes have been examined from a deep ocean perspective, but there is a need to understand the mechanisms involved in the retention of biogenic particles at the surface (Wassmann 1997, Boyd \& Trull 2007). Iversen et al. (2010) argue that residence time of particles in the upper water column is important for addressing the relative importance of bacteria versus flux-feeding zooplankton. Our results suggest that in highly productive regions, where mesozooplankton producing fast-sinking FP are important, rapid degrading processes $(<48 \mathrm{~h})$, such as fragmentation by filter-feeding copepods, are more import than processes involving microbial degraders.

\section{CONCLUSIONS}

Large FP produced by Calanus finmarchicus can contribute significantly to the vertical flux of biogenic matter, but generally, FP captured in sediment traps fall short of pelagic FP production. Our experiments demonstrate that large $C$. finmarchicus FP are relatively difficult to degrade, as a detectable effect of the plankton community $<180 \mu \mathrm{m}$ was only visible after $72 \mathrm{~h}$. However, combined effects of both the microbial community and large copepod grazers resulted in more efficient degradation rates.

Our first hypothesis predicting a more efficient retention community close to the chl $a_{\max }$ compared to deeper water was not tested appropriately, as the time frame of the experiment $(20 \mathrm{~h})$ was too short to detect a response from the microbial community. Our second hypothesis, that large FP requires a more efficient retention community than smaller FP, was supported. Also, our results imply that mesozooplankton such as Calanus finmarchicus may be more important than protozooplankton for the degradation of large FP. This contrasts with previous studies on smaller FP pellets.

We suggest that the degradation of FP can prolong the pelagic productive season by retaining organic material and nutrients in the euphotic zone. A strong pelagic food web could thus provide positive feedback through retention processes.

Acknowledgements. We are grateful to T. Tamelander and the crew of RV 'Hyas' and RS 'Gideon' for assistance in the field, and to H. C. Eilertsen for providing the Rhodomonas culture. M.R. was financed by the CONFLUX project (Tromsø Forskningsstiftelse, UiT), and C.W.R. was financed through the MERCLIM (funded by Research Council of Norway, contract no. 184860/S30. L.S. and C.S. were financially supported through a PhD and a postdoc scholarship, respectively, from the University of Tromsø, Norway. The present study was also supported by ARCTOS, the research network for arctic marine biology (www.arctosresearch.net). 


\section{LITERATURE CITED}

Andreassen IJ, Wassmann P, Ratkova TN (1999) Seasonal variation of vertical flux of phytoplankton and biogenic matter at Nordvestbanken, north Norwegian shelf in 1994. Sarsia 84:227-238

Ayukai T, Hattori H (1992) Production and downward flux of zooplankton fecal pellets in the anticyclonic gyre off Shikoku, Japan. Oceanol Acta 15:163-172

> Boyd PW, Trull TW (2007) Understanding the export of biogenic particles in oceanic waters: Is there consensus? Prog Oceanogr 72:276-312

Cadée GC, Gonzalez H, Schnackschiel SB (1992) Krill diet affects fecal string settling. Polar Biol 12:75-80

> Checkley DM, Davis RE, Herman AW, Jackson GA, Beanlands B, Regier LA (2008) Assessing plankton and other particles in situ with the SOLOPC. Limnol Oceanogr 53: 2123-2136

De Troch M, Cnudde C, Vyverman W, Vanreusel A (2009) Increased production of faecal pellets by the benthic harpacticoid Paramphiascella fulvofasciata: importance of the food source. Mar Biol 156:469-477

Eilertsen E, Taasen JP (1984) Investigations of the plankton community of Balsfjorden, northern Norway. The phytoplankton 1976-1978. Environmental factors, dynamics of growth, and primary production. Sarsia 69:1-15

Eilertsen HC, Schei B, Taasen JP (1981) Investigations on the plankton community of Balsfjorden, northern Norway: the phytoplankton 1976-1978. Abundance, species composition and succession. Sarsia 66:129-141

Frost BW (1972) Effects of size and concentration of food particles on the feeding behaviour of the marine planktonic copepod Calanus pacificus. Limnol Oceanogr 17: 805-815

González HE, Smetacek V (1994) The possible role of the cyclopoid copepod Oithona in retarding vertical flux of zooplankton faecal material. Mar Ecol Prog Ser 113: 233-246

Hansen PJ (1992) Prey size selection, feeding rates and growth dynamics of heterotrophic dinoflagellates with special emphasis on Gyrodinium spirale. Mar Biol 114: 327-334

> Hansen PJ, Bjørnsen PK, Hansen BW (1997) Zooplankton grazing and growth: scaling within the $2-2000 \mu \mathrm{m}$ body size range. Limnol Oceanogr 42:687-704

> Hofmann EE, Klinck JM, Paffenhofer GA (1981) Concentrations and vertical fluxes of zooplankton fecal pellets on a continental shelf. Mar Biol 61:327-335

Holm-Hansen O, Lorenzen CJ, Holmes RW, Strickland JDH (1965) Fluorometric determination of chlorophyll. J Cons Int Explor Mer 30:3-15

Iversen MH, Poulsen LK (2007) Coprorhexy, coprophagy, and coprochaly in the copepods Calanus helgolandicus, Pseudocalanus elongatus, and Oithona similis. Mar Ecol Prog Ser 350:79-89

> Iversen MH, Nowald N, Ploug H, Jackson GA, Fischer G (2010) High resolution profiles of vertical particulate organic matter export off Cape Blanc, Mauritania: degradation processes and ballasting effects. Deep-Sea Res I 57:771-784

> Jakobsen HH, Hansen PJ (1997) Prey size selection, grazing and growth response of the small heterotrophic dinoflagellate Gymnodinium sp. and the ciliate Balanion comatum - a comparative study. Mar Ecol Prog Ser 158:75-86 - Lampitt RS, Noji T, von Bodungen B (1990) What happens to zooplankton faecal pellets? Implications for material flux. Mar Biol 104:15-23

Menden-Deuer S, Lessard EJ (2000) Carbon to volume relationships for dinoflagellates, diatoms, and other protist plankton. Limnol Oceanogr 45:569-579

Møller EF, Borg CMA, Jonasdottir SH, Satapoomin S, Jaspers C, Nielsen TG (2011) Production and fate of copepod fecal pellets across the Southern Indian Ocean. Mar Biol 158:677-688

Noji T (1991) The influence of macrozooplankton on vertical particulate flux. Sarsia 76:1-9

Olli K, Wexels Riser C, Wassmann P, Ratkova T, Arashkevich E (2001) Vertical export of biogenic matter, particulate nutrients and mesozooplankton faecal pellets off the NW coast of Galicia. Prog Oceanogr 51:423-441

Paffenhöfer GA, Knowles S (1979) Ecological implications of faecal pellet size, production and consumption by copepods. J Mar Res 37:35-49

Paffenhöfer GA, Van Sant KB (1985) The feeding response of a marine planktonic copepod to quantity and quality of particles. Mar Ecol Prog Ser 27:55-65

> Patonai K, El-Shaffey H, Paffenhôfer GA (2011) Sinking velocities of fecal pellets of doliolids and calanoid copepods. J Plankton Res 33:1146-1150

> Ploug H, Iversen MH, Koski M, Buitenhuis ET (2008) Production, oxygen respiration rates, and sinking velocity of copepod fecal pellets: direct measurements of ballasting by opal and calcite. Limnol Oceanogr 53:469-476

Poulsen LK, Iversen MH (2008) Degradation of copepod fecal pellets: key role of protozooplankton. Mar Ecol Prog Ser 367:1-13

> Poulsen LK, Kiørboe T (2006) Vertical flux and degradation rates of copepod fecal pellets in a zooplankton community dominated by small copepods. Mar Ecol Prog Ser 323:195-204

Poulsen LK, Moldrup M, Berge T, Hansen PJ (2011) Feeding on copepod fecal pellets: a new trophic role of dinoflagellates as detritivores. Mar Ecol Prog Ser 441:65-78

Putt M, Stoecker D (1989) An experimentally determined carbon:volume ratio for marine 'oligotrichous' ciliates from estuarine and coastal waters. Limnol Oceanogr 34: 1097-1103

Reigstad M (2000) Plankton community and vertical flux of biogenic matter in north Norwegian fjords: regulating factors, temporal and spatial variations. PhD thesis, University of Tromsø

Reigstad M, Wexels Riser C, Svensen C (2005) Fate of copepod faecal pellets and the role of Oithona spp. Mar Ecol Prog Ser 304:265-270

Reigstad M, Wexels Riser C, Wassmann P, Ratkova T (2008) Vertical export of particulate organic carbon: attenuation, composition and loss rates in the northern Barents Sea. Deep-Sea Res II 55:2308-2319

Small LF, Fowler SW, Ünlü MY (1979) Sinking rates of natural copepod fecal pellets. Mar Biol 51:233-241

Svendsen H (1995) Physical oceanography of coupled fjordcoast systems in northern Norway with special focus on frontal dynamics and tides. In: Skjoldal HR, Hopkins C, Erikstad KE, Leinaas HP (eds) Ecology of fjords and coastal waters. Elsevier, Amsterdam, p 149-164

Turner JT (2002) Zooplankton fecal pellets, marine snow and sinking phytoplankton blooms. Aquat Microb Ecol 27:57-102

Turner JT, Ferrante G (1979) Zooplankton fecal pellets in aquatic ecosystems. Bioscience 29:670-677 
Urban-Rich J (2001) Seston effects on faecal pellet carbon concentrations from a mixed community of copepods in Balsfjord, Norway, and the Antarctic Polar Front. ICES J Mar Sci 58:700-710

Urban-Rich J, Nordby E, Andreassen IJ, Wassmann P (1999) Contribution by mesozooplankton fecal pellets to the carbon flux on Nordvestbanken, north Norwegian shelf in 1994. Sarsia 84:253-264

Utermöhl H (1958) Zur Vervollkommnung der quantitativen Phytoplankton Methodik. Int Ver Theor Angew Limnol Verh 9:1-38

Viitasalo M, Rosenberg M, Heiskanen AS, Koski M (1999) Sedimentation of copepod fecal material in the coastal northern Baltic Sea: Where did all the pellets go? Limnol Oceanogr 44:1388-1399

Wassmann P (1997) Retention versus export food chains: processes controlling sinking loss from marine pelagic systems. Hydrobiologia 363:29-57

Wassmann P, Hansen L, Andreassen IJ, Wexels Riser C, Urban-Rich J (1999) Distribution and sedimentation of faecal pellets on the Nordvestbanken shelf, northern Norway, in 1994. Sarsia 84:239-252

Wassmann P, Reigstad M, Oygarden S, Rey F (2000) Seasonal variation in hydrography, nutrients, and suspended

Editorial responsibility: Hans Heinrich Janssen, Oldendorf/Luhe, Germany biomass in a subarctic fjord: applying hydrographic features and biological markers to trace water masses and circulation significant for phytoplankton production. Sarsia 85:237-249

- Wexels Riser C, Wassmann P, Olli K, Arashkevich E (2001) Production, retention and export of zooplankton faecal pellets on and off the Iberian shelf, north-west Spain. Prog Oceanogr 51:423-442

Wexels Riser C, Wassmann P, Olli K, Pasternak A, Arashkevich E (2002) Seasonal variation in production, retention and export of zooplankton faecal pellets in the marginal ice zone and central Barents Sea. J Mar Syst 38:175-188 Wexels Riser C, Reigstad M, Wassmann P, Arashkevich E, Falk-Petersen S (2007) Export or retention? Copepod abundance, faecal pellet production and vertical export in the marginal ice zone through snap shots from the northern Barents Sea. Polar Biol 30:719-730

- Wexels Riser C, Wassmann P, Reigstad M, Seuthe L (2008) Vertical flux regulation by zooplankton in the northern Barents Sea during Arctic spring. Deep-Sea Res II 55: 2320-2329

> Wexels Riser C, Reigstad M, Wassmann P (2010) Zooplankton-mediated carbon export: a seasonal study in a northern Norwegian fjord. Mar Biol Res 6:461-471

Submitted: June 16, 2011; Accepted: May 8, 2012

Proofs received from author(s): August 8, 2012 